\title{
Electromyographic Studies on Facial Muscles of Japanese-American Hybrids
}

\author{
Shiro Kondo', Masahiko SATO'), Yasuyuki KiKuCHI ${ }^{3)}$, \\ Mamoru Tomita ${ }^{4)}$, Morihiko Okada ${ }^{5)}$ and Atsushi Hayami ${ }^{6)}$
}

Comparing the motor representation in the cerebral cortex of man (PENFIELD \& RASMUSSEN '52) with those of the other animals (Woolsey '52), we are able to understand that development of the communication by speech and facial expression is one of the most essential characteristics of man. Furthermore, it is a general understanding that some parts of the emotional state are expressed more effectively by facial expression than by speech and that the European or American people are very clever in facial expression as compared with the Japanese. Therefore, it is valid to consider that facial expression is an important problem in the field of anthropology.

Since the day of DARWIN (1872), facial expression has been investigated by many scholars. Recently, some authors published electromyographic studies on each facial muscle in some facial expressions (ToKIZANE '54; HAYAKAwA '56; Kondo et al. '66; Sumitsuji et al. '66). Especially, Kondo and his co-workers proposed the existence of the lateral dominance in nervous control of the facial muscle. The present study was designed to investigate the lateral dominance in the facial muscle of Japanese-American hybrid children.

\section{MATERIALS AND METHOD}

Five investigations were carried out between the period from March 1964 to March 1966. 39 boys and 17 girls were examined in total. However, all girls were excluded from subjects in the present paper, because it was of ten difficult to make girls exhibit steady facial performances, probably owing to some emotional disturbances. In addition, the following boys were omitted as well: 1) whose electromyographic records were unsuccessful; 2) whose racial details were unknown. Eventually, 27 boys aged from 10 to 17 were made subjects of this paper.

Each subject was seated in a portable shield box, and was asked to try following facial performances, each of those to be continued for 10-20 seconds as steadily as possible: 1) raising the right eyebrow; 2) raising the left eyebrow; 3) raising both eyebrows ; 4) pulling the right corner of the mouth sideways; 5) pulling the left corner of the mouth sideways; 6) pulling corners of the mouth. At each trial, a hand-mirror was employed to facilitate the performances. Action potentials were led bilaterally with bipolar surface electrodes from the frontal muscle and oral muscles during raising the eyebrow and pulling

This work was supported by the Ministry of Education and carried out as a part of JIBP. 
the mouth corner. The electrodes were plain silver plates whose diameter was $5 \mathrm{~mm}$. The global EMG was recorded to the magnetic tape using a FM-adaptor. Being played back, the data were fed to an automatic frequency analyzing integrator which had seven separate filtering frequency bands, $i . e .-20,20-40,40-60,60-100,100-150,150-300,300-$ cps, whose frequency characteristics had already been reported (SA TO '64). The integration time was 5 seconds. In some cases, DC amplifiers and a pen-recording oscillograph were employed supplementarily.

\section{RESULTS}

During the bilateral performances the amplitude of the global EMG of right muscles tended to be greater than those in left muscles in most subjects, independently whether they belonged to negro hybrids or white hybrids (Fig. 1). As to the unilateral performances, the present authors obtained the ratio of the mean amplitude of the EMG in active side to that in the contralateral one, and compared it mutually over both sides (Fig. 2). As indicated in this figure, slightly more subjects showed higher value of this ratio in the right side.

So far as the frequency analysis of the global EMG was concerned, the present authors did not intend to carry out a systematic analysis of the facial muscles, but to obtain some frequency aspects of test muscles for comparison with those in control (Kondo et al. op. cit.). The ratio of lower frequency components below $100 \mathrm{cps}$ to higher frequency components above $100 \mathrm{cps}$ (slow-wave ratio) was

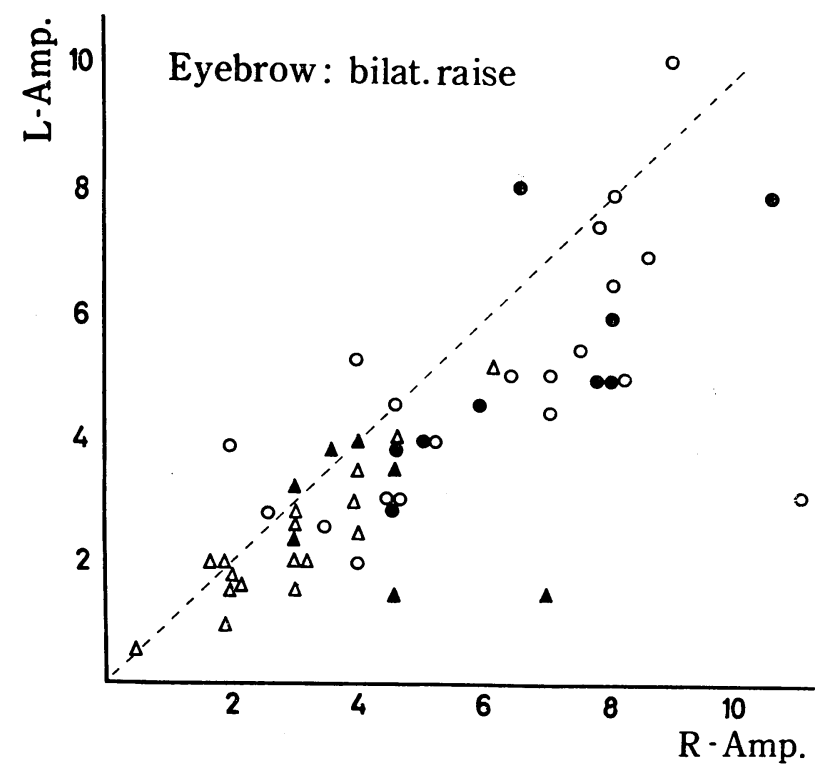

Fig. 1. Comparison of the mean amplitude of the global EMG (shown in arbitrary unit) from right ( $R-a m p$ ) and left (L-amp) side in the bilateral performance. Triangles: eyebrow raising, circles: mouth pulling. Black: negro hybrids, white: white hybrids. adopted for a plain expression of the frequency aspects of the EMG. That is, higher value of this ratio means that lower frequency components are more dominant in the frequency spectra. Although the components below $20 \mathrm{cps}$ were excluded from the lower components on account of the movement artifacts intermingled within this band, this ratio could be expected to indicate the general tendency of the frequency aspects.

As for the eyebrow raising in the white hybrids there were no differences 


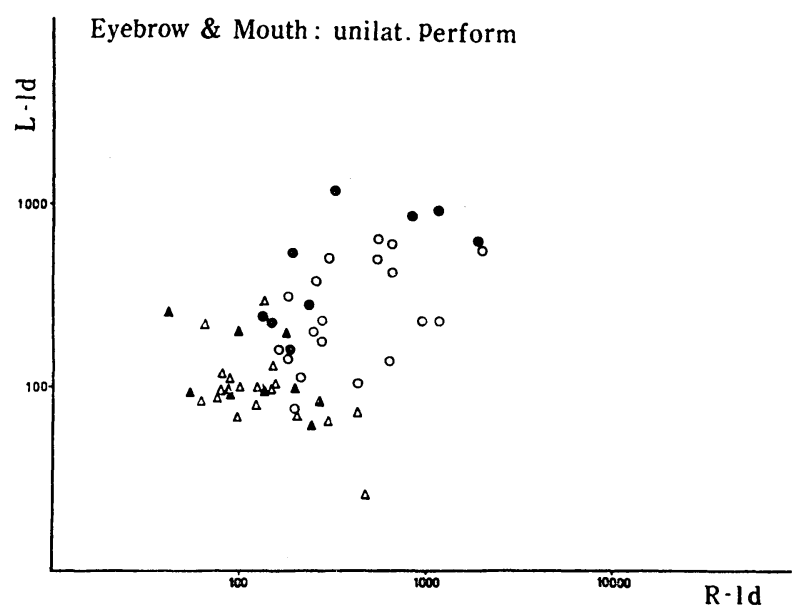

Fig. 2. Comparison of the ratio of the mean amplitude of the global EMG in active side to that in the contralateral side between the right side performances (R-ld) and the left side ones (L-ld). Triangles: eyebrow raising, circles: mouth pulling. Black: negro hybrids, white: white hybrids. between the number of subjects who showed lower value in this ratio in the right test muscles and the number of those who showed lower ratio in the left ones. On the contrary, in the negro hybrids more than half of the subjects showed lower ratio in the right muscle than in the left ones. In the case of pulling mouth corner, independently of whether the subjects belonged to negro hybrids or white hybrids, those who showed lower ratio in the right test muscles were decidedly major in number.

(see Table 1)

Table 1. Comparison of the number of the subjects who showed slow-wave ratio in the right test muscles and the number of those who showed it in the left ones during each performance.

$=$ Number of the subjects who showed approximately the same ratio in both sides.

* Number of the subjects who showed low amplitude global EMG (included in this total).

** Number of the subjects who showed extreme low amplitude (excluded from this total).

\begin{tabular}{|c|c|c|c|c|c|c|}
\hline & $\begin{array}{l}\text { right } \\
\text { eyebrow } \\
\text { raising }\end{array}$ & $\begin{array}{l}\text { left } \\
\text { eyebrow } \\
\text { raising }\end{array}$ & $\begin{array}{l}\text { both } \\
\text { eyebrows } \\
\text { raising }\end{array}$ & $\begin{array}{l}\text { right } \\
\text { m. corn. } \\
\text { pulling }\end{array}$ & $\begin{array}{l}\text { left } \\
\text { m. corn. } \\
\text { pulling }\end{array}$ & $\begin{array}{l}\text { both } \\
\text { m. corns. } \\
\text { pulling }\end{array}$ \\
\hline W-hybrids & & & & & & \\
\hline right & 6 & 7 & 5 & 14 & 4 & 13 \\
\hline left & 7 & 6 & 5 & 1 & 4 & 4 \\
\hline$=$ & 5 & 3 & 9 & 0 & 3 & 2 \\
\hline$*$ & 11 & 9 & 4 & 9 & 7 & 0 \\
\hline$* *$ & 1 & 3 & 0 & 4 & 8 & 0 \\
\hline N-hybrids & & & & & & \\
\hline right & 4 & 5 & 3 & 4 & 3 & 5 \\
\hline left & 1 & 2 & 1 & 0 & 0 & 0 \\
\hline$=$ & 2 & 1 & 4 & 2 & 2 & 3 \\
\hline$*$ & 3 & 4 & 0 & 1 & 1 & 0 \\
\hline$* *$ & 1 & 0 & 0 & 2 & 3 & 0 \\
\hline
\end{tabular}




\section{DISCUSSION}

Although the present authors could not find out by mere observations with unaided eyes whether the unilateral performances were done more easily or intensely in a specific side than in the other, the ratio of the mean amplitude of the global EMG from the active side to that from the contralateral side was higher frequently in the right side performances than in the left side ones. During the bilateral performances in most subjects, the amplitude of the EMG was larger in the right muscles than in the left ones. These tendencies might mean that the voluntary control over contraction of the facial muscles tested were established more effectively in the right side than in the left also in the present subjects.

So far as the frequency spectra of the global EMG were concerned, it has been supposed that the cycles of the EMG are dependent mainly upon the degree of syntonizing or synchronizing activities of different motor units and that proprioceptive impulses from muscle receptors have synchronizing and asynchronizing effects upon different motor units activities (SATo \& TSURUmA '67). Laying stress on the asynchronizing effect of impulses from the muscle spindle on motor unit discharges, Kondo ('64) emphasized a connection between the higher frequency components in the global EMG and the gamma motor loop. Based on this consideration, it was proposed that higher frequency dominance in the facial muscles of a specific side during bilateral performances meant the existence of a sort of lateral dominance in the facial muscle like the handedness or the eyedness and that in Japanese male adult subjects the preferred side was considered to be the right (Kondo et al. op. cit.). As for the present result, therefore, it may be presumed that the dominant side for pulling the mouth corner is the right irrespective of the racial origins of subjects and that for the eyebrow raising is the right in negro hybrids though obscure in the white hybrids. As a general tendency it may be pointed out that the lateral dominance for the facial muscles is not obviously established in the present subjects as compared with the Japanese subjects (Kondo et al. op. cit.). From the amplitude measurement and frequency analysis of the global EMG, it may be valid to conclude that also in the Japanese-American hybrid children there exists a lateral dominance in voluntary control over the facial muscle. However, it remains a matter of uncertainty whether the difference of intensity of the laterality between the Japanese subjects and the present ones is derived from some factors in racial differences or not.

\section{SUMMARY}

From March 1964 to March 1966, five surveys were carried out to research the 
lateral dominance in the facial muscles of 27 Japanese-American boys aged from 10 to 17 . While each subject raised the eyebrow(s) or pulled the mouth corner (s) unilaterally or bilaterally, the global EMG was led bilaterally with the bipolar surface electrodes, $5 \mathrm{~mm}$ in diameter, from frontal and oral muscles. During the bilateral performances the amplitude of the EMG from test muscles in the right side tended to be greater than that in the left in most subjects irrespectively of whether they belonged to the negro hybrids or white hybrids. Also in the cases of the unilateral performances many subjects showed, in the right side, higher value of the ratio of the amplitude of the EMG in active side to that in the contralateral side. As the results of the frequency analysis of the global EMG, it was found that during bilateral performances of pulling mouth corners the ratio of lower frequency components below $100 \mathrm{cps}$ to higher ones over $100 \mathrm{cps}$ was, in both groups, usually lower in the right test muscles than in the left ones, and that during the bilateral performances of the eyebrow, more than half of the negro hybrids showed lower ratio in the right muscle than in the left one though no difference was indicated in number of subjects in case of white hybrids. From the above results it was concluded that a lateral dominance did exist in the ability of voluntary control over the facial muscle in the JapaneseAmerican hybrid children as same as in the Japanese. Differences in the intensity of the laterality between the hybrids and Japanese were discussed.

\section{REFERENCES}

DARWIN, C., 1872: The expression of the emotions in man and animals. P. 374, John Murray, London.

HAYAKAWA, H., 1956: Electromyography of the facial palsy. Kindenzu 21-38, Kinbara, Tokyo. (in Japanese)

Kondo, S., 1964: A study on human erect posture and locomotion. Proc. 7th Internat. Joint Meet. Anthrop. \& Ethnol.

Kondo S., M. Tomita, M. Okada, A. Hayami \& M. SA to, 1966: Electromyographic studies of facial muscles (I). Proc. Joint Meet. Anthrop. Soc. Nippon \& Jap. Soc. Ethnol., 20, 153-155. (in Japanese).

Penfield, W. \& T. Rasmussen, 1952: The cerebral cortex of man. Macmillan, New York, P. 235.

SAто, M., 1964: Frequency components of the Electromyogram led with the bipolar surface electrodes. J. Anthrop. Soc. Nippon, 72, 92-106, (in Japanese with English summary).

SATO, M. \& S. TSURUMA, 1967: A scope of the frequency analysis of the electromyogram. Annual Rep. Phys. Educ., 1, 7-28.

Sumitsuji, N., K. Matsumoto \& Z. Kaneko, 1965: A new method to study facial expression using electromyography. Electromyography, 5, 269-272.

TOKIZANE H., 1954: The electromyography of the facial muscle. Kindenzu-rinshotekioyo, Nagai-shoten, Osaka, P. 92-98. (in Japanese).

Woolsey, C. N., 1952: The biology of mental health and disease. Milbunk Memor. Fund. 
New York, P. 139.

The authors are deeply indebted to Mrs. Miki SAWADA, Directress of Elizabeth Sanders Home, and Prof. Akiyoshi Suda for permission to carry out this investigation.

${ }^{1)}$ Research Institute of Primates Study, University of Kyoto

2) Department of Ergonomics, Kyūshü Institute of Design

${ }^{3}$ Department of Industrial Design, Faculty of Technology, University of Chiba

4) Department of Anatomy, Faculty of Medicine, University of Chiba

${ }^{5)}$ Department of Anthropology, Faculty of Science,

University of Tokyo

6) Division of Anthropology \& Kinesiology, Japan Women's College of Physical Education

日米混血児の表情筋の筋電図学的研究

近藤四郎1) ・ 佐藤方彦 22 ・菊池安行 ${ }^{32}$

富田守4) ・咸田守彦5)・早弓惊6)

1964年 3 月より1966年 3 月まで Elizabeth Sanders Home 混血览調査に 5 回に亘つて参加し, 眉 上げ，口角引きの表情運動に伴う筋電図を直径 $5 \mathrm{~mm}$ の銀盤電極による双極誘導で記録し，振市を測定 するととむに周波数分析を行つた。両側運動中の筋電図振巾は $\mathrm{N}$ 群（米黒人 $\times$ 日本人）あるいはW群（米 白人 $\times$ 日本人) を問わず大多数の被検者に於いて右側の筋よりのあのの方が大きいてとが認められた。片 側運動中, 運動側と刘側との筋電図振巾の比は右側運動の方が高い被検者の方が多かつた。両側性の口蟹 引きでは $\mathrm{N}, \mathrm{W}$ 群とも右側つ筋からの筋電図がより速波成分比率が高く, 両側性眉上げでは $\mathrm{N}$ 群において は右側の筋の方がより速波成分比率が高く，W群に於いては相違を認め難かつた。以上の傾向は日本人成 人男子に抢いて認められた表情筋の随意運動の右側優位（近藤ら1966）が当該混血児に於いても存在する ととを示すあのと考えられよう。筋電図速波成分の出現と Gamma 運動系の関連 (KONDO 1964) 飞基 き, 表情筋運動の一側優位性の機序に就いて若干の考察を加えた。
1) 京都大学霊長類研究所
2) 九州芸術工科大学人間工学教室
3) 千葉大学工学部工業意匠学科
4) 千葉大学医学部解剖学教室
5) 東京大学理学部人類学教室
6) 日本女子体育大学人類学運動力学研究室 